$\angle$ Research Square

\title{
Oral Contraceptive Used More than 5 Years is Associated with Increased Risk of Breast Cancer: A Meta-Analysis of 28,776 South East Asian Women
}

Ricvan Dana Nindrea ( $\square$ ricvandana7@gmail.com )

Universitas Gadjah Mada Fakultas Kedokteran https://orcid.org/0000-0002-1844-3323

\section{Teguh Aryandono}

Universitas Gadjah Mada Fakultas Kedokteran

Sumadi Lukman Anwar

Universitas Gadjah Mada Fakultas Kedokteran

\section{Lutfan Lazuardi}

Universitas Gadjah Mada Fakultas Kedokteran

Wirsma Arif Harahap

Universitas Andalas Fakultas Kedokteran

Iwan Dwiprahasto

Universitas Gadjah Mada Fakultas Kedokteran

\section{Research article}

Keywords: breast cancer, five years, oral contraceptive, Southeast Asia

Posted Date: November 19th, 2019

DOl: https://doi.org/10.21203/rs.2.17486/v1

License: (1) This work is licensed under a Creative Commons Attribution 4.0 International License. Read Full License 


\section{Abstract}

Background: Breast cancer associated with variety of hormonal inter-ethnic and reproductive factors. Duration of oral contraceptives use with breast cancer risk is not well understood in Southeast Asian women. Methods: A comprehensive literature search of published articles from January 2001 to June 2019 (PubMed, ProQuest, and EBSCO online article databases) and meta-analysis were performed to link the duration of oral contraceptive application with risk of breast cancer among women in Southeast Asia. We identified the reference category, being $\leq 5$ years' duration and $>5$ years' duration of oral contraceptive application. We use the Fixed and randomeffect models to rely pooled odds ratios (OR). Egger's and Begg's test used for publication bias was presented with funnel plots. All analyzed data in Review Manager 5.3 (RevMan 5.3) and Stata version 14.2. Results: A total of 385 studies were reviewed and 10 studies involving a total of 28,776 women were included in a metaanalysis. This study found a slight increase in breast cancer risk in Southeast Asian women with oral contraceptives application $\leq 5$ years with $\mathrm{OR}=1.21(95 \% \mathrm{Cl} 0.96-1.52, \mathrm{p}>0.05)$. A higher risk of breast cancer was found in women with oral contraceptive application $>5$ years with $\mathrm{OR}=2.66(95 \% \mathrm{Cl} 1.79-3.94, \mathrm{p}<0.00001)$. Publication bias and heterogeneity were not found particularly in a group of Southeast Asian women with oral contraceptive application for more than 5 years. Conclusion: Oral contraceptives use more than 5 years are at a higher risk in breast cancer among women in Southeast Asia. Although other reproductive factors including age at first childbirth, menarche, menopause, and lactation might influence the risk of breast cancer. Keywords: breast cancer, five years, oral contraceptive, Southeast Asia

\section{Background}

Breast cancer is the most frequent cancer and the second leading cause of cancer-associated mortality among women worldwide. A total of 2,088,849 new cases and 626,679 deaths have been related to breast cancer in 2018 [1]. Multifactorial etiology has been identified as one of the risk factors known is oral contraceptive application [2,3].

Previous studies have revealed that combined oral contraceptives reduce endometrial and ovarian cancer risks through ovulation suppression $[4,5]$. These studies found contrary results of contraceptive pills use with occurrence of breast cancer. An increased breast cancer risk correlated with used in oral contraceptive pills $[4,5,6]$ meanwhile other studies $[7,8,9,10]$ have shown inconclusive results.

Other determinants of oral contraceptive use and the occurrence of breast cancer are the length of the use, doseresponse, and age of the users. Another study showed a significant elevate in the number of young women who use oral hormonal contraceptive as well as women who begin to use oral contraceptives before the age of 20 [2]. Furthermore, the studies found there is no association between breast cancer and oral contraceptives use [2,4]. Increased breast cancer risk particularly in women with oral contraception application for more than 4 years before the first pregnancy [5]. Another study reported breast cancer risk increasing in the oral contraceptives pills use for more than eight years [6].

Oral contraception has recently emerged as the third most common method for family planning and the most widely distributed across the globe compared to other contraceptive methods. It is estimated that $6.4 \%$ of Asian women use contraceptive pills [11]. Meanwhile, the proportion of oral contraceptive users in Southeast Asia is $12.8 \%$ [12]. Oral contraceptive users by country in Southeast Asia revealed that Thailand as the highest users 
(35\%), followed by Indonesia (13.6\%) and Vietnam (8.6\%) [11,13]. Therefore, oral contraceptive application in Southeast Asia is relatively high yet the correlation with breast cancer risk is still under study.

\section{Methods}

\section{Study design and research sample}

In this meta-analysis study, we followed the Preferred Reporting Items for Systematic Reviews and MetaAnalysis (PRISMA) Statement [14]. The samples of this research included published research articles which were published from January 2001 to June 2019 in PubMed, ProQuest, and EBSCO of online article databases. In each study we identified the reference category, being $\leq 5$ years' duration and $>5$ years' duration of the application of oral contraceptive.

\section{Operational definitions}

This study comprised of independent variables, (a) $\leq 5$ years' duration and (b) $>5$ duration of oral contraceptive use, and a dependent variable, i.e. breast cancer risk.

\section{Research procedure}

The procedure of this research was started by collecting data through published research articles identification on the oral contraceptive application length and the risk of breast cancer in Southeast Asian women on PubMed online article databases, ProQuest, and EBSCO (Figure 1).

These following keywords are used treating as title or abstract for the literature search: ("oral contraceptive" OR "hormonal oral") AND ("breast cancer" OR "breast neoplasms"). We found 385 articles were identified by examining the article titles, abstract and full-text. Furthermore, this study classified the research articles into two groups based on the oral contraceptive application length with $\leq 5$ years' duration and $>5$ years' duration.

The article will be excluded if it is: (a) not breast cancer outcome, (b) conducted by using other study designs other than case-control or cohort study (c) included insufficient data for extraction.

\section{Data collection technique}

Online searching was performed in data collection. The collected data was limited by the articles written in English. The article type was limited to original research one. The publication date of the articles was limited from January 2000 to May 2019. The research subject was limited to humans only. Conceivably significant title unique articles were inspected, while the insignificant articles were prohibited. Those possibly significant unique articles will be evaluated in full-content structure, while then the unessential articles were excluded. The sample inclusion criterias were researched on the duration of oral contraceptive application, including $\leq 5$ years' duration or $>5$ years' duration, and breast cancer in Southeast Asian women with restrospective study and prospective study design. The exclusion criterias were (a) the inclusion criterias were unsatisfyingly fulfilled, (b) the articles were unavailable in full-text form, and/or (c) the data provided in the full-text form was not sufficient for extraction of datas. The following datas were also collected from the articles: the name of the original writter, study location, study type, and a number of several samples. 
The information from all of the articles that fulfilled inclusion criterias per under a standardized protocol carefully extracted by two investigator, while contradictions were settled by three different investigators. Newcastle-Ottawa Quality Assessment Scale (NOS) was performed for evaluation quality of research articles. Articles were indicated poor (score 0-3), moderate (score 4-6) and high quality (score 7-9) [15].

\section{Data analysis}

Data analysis was conducted to get pooled and combined odd ratios of the collected articles. Odd ratio with 95\% confidence intervals (Cls) was utilized to pool the results. These test presented the minimum statistical power article with limited numbers and sample sizes was indicated by $\mathrm{I}^{2}>50 \%$ significantly heterogeneity. Assesment significant heterogeneity used a random-effect model and homogeneity used a fixed-effect model. Review Manager 5.3 (RevMan 5.3) was used to analyze the data. Publication bias was performed funnel plots and Egger's and Begg's tests, statistically significant publication bias p-value $<0.05$. Stata version 14.2 was conducted to analyze publication bias. A two-tailed $P$-value of $<0.05$ was considered statistically significant.

\section{Results}

Reviewing process was held to select 10 studies related to the duration of oral contraceptive application with breast cancer risk in Southeast Asian women with a total 28,776 samples patients (Table 1) [13,16-24].

A meta-analysis study was performed to determine the duration of oral contraceptive application and breast cancer risk in Southeast Asian women (Figure 2). The figure presented an insignificant result of $\leq 5$ years' duration of oral contraceptive application and breast cancer risk in Southeast Asian women with OR $=1.21$ (95\% $\mathrm{Cl} 0.96-1.52, \mathrm{p}>0.05)$. The Heterogeneity test in these studies $\left(P_{\text {heterogeneity }}=0.0004 ; I^{2}=70 \%\right)$ resulted in a variety of heterogeneous results on the breast cancer risk. In contrast, oral contraceptive application for $>5$ years and breast cancer risk in Southeast Asian women had a significant result with OR $=2.66(95 \% \mathrm{Cl} 1.79-3.94, \mathrm{p}$ $<0.00001)$. Different from the $\leq 5$ years' application duration, heterogeneity tests in these studies $\left(P_{\text {heterogeneity }}=\right.$ $0.14 ; I^{2}=45 \%$ ) resulted in multifariousness of homogeneous research on breast cancer risk.

Publication bias in articles collected desribed by presenting Funnel plots on the duration of oral contraceptive application with breast cancer risk among women in Southeast Asia (Figure 3). In figure 3, results showed as significant publication bias detected in articles on oral contraceptive $\leq 5$ years' duration of oral contraceptive and risko of breast cancer among women in Southeast Asia with Egger's test $(P=0.011)$ and Begg's test $(P=$ 0.09). In contrast, in articles on $>5$ years' duration of oral contraceptive use and risk of breast cancer among women in Southeast Asia (Figure 4), our study found that there was no significant publication bias with Egger's test $(p=0.270)$ and Begg's test $(p=0.308)$.

Subgroup analysis for oral contraceptive use and breast cancer risk in Southeast Asia (Table 2). Ten studies assessing oral contraceptive application and breast cancer risk, seven were case-control studies [13,16-18,21,22] with Pooled Odds Ratio (POR) 1.52 (1.06-2.18), heterogeneity test in these studies $\left(P_{\text {heterogeneity }}=<0.001 ; I^{2}=\right.$ $90 \%)$ resulted in various heterogeneous research on breast cancer risk, and three were cohort studies $[19,20]$ with 
POR $1.34(0.98-1.84)$, heterogeneity test in these studies $\left(P_{\text {heterogeneity }}=0.28 ; I^{2}=21 \%\right)$ resulted in a variety of homogeneous research on the breast cancer risk.

Study quality found eight studies with high NOS scores [13,18-24], POR 1.51 (1.09-2.10), heterogeneity test in these studies $\left(P_{\text {heterogeneity }}=<0.001 ; I^{2}=88 \%\right)$ resulted various heterogeneous research on the breast cancer risk. Two studies with low NOS scores [16,17], POR 1.35 (0.80-2.27), heterogeneity test in these studies ( $P_{\text {heterogeneity }}$ $=0.17 ; 1^{2}=48 \%$ ) resulted various homogeneous research.

The oral contraceptive use duration and breast cancer risk in Southeast Asian countries was presented in Table 3. Our study found that there is an association of $>5$ years' duration of oral contraceptive application and breast cancer risk in Southeast Asian women, while $\leq 5$ years' duration of oral contraceptives is not associated to breast cancer risk in Southeast Asian women.

Indonesia has the largest figure of women used oral contraceptives for $>5$ years with POR for breast cancer risk was 2.67 (1.62-4.40), followed by Thailand and Malaysia with POR for breast cancer risk were 2.56 (1.08-6.08) and 2.28 (0.84-6.16), respectively.

\section{Discussion}

This study result showed that $>5$ years' length of oral contraceptive pills use increased breast cancer risk in Southeast Asian women with risk opportunity was more than doubled. The results were also homogeneous which means the studies will give consistent or insignificantly different if the study performs at the same time and place.

Furthermore, Indonesia has been known that this country has the greatest risk opportunities for breast cancer, followed by Thailand and Malaysia. Our study findings described possibly relate to the high rates of oral contraceptive application in those country mentioned in advance [11,13,24].

The previous studies found breast cancer incidence related to oral contraceptive application in several ethnicities. Non-Hispanic Caucasians have the highest percentage of oral contraceptive application (55\%) as well as the highest number of incidence of breast cancer (6\%). Interestingly, the lowest proportion of oral contraception application (37.5\%) yet being the second-highest in the percentage of breast cancer incidence (5.7\%) in non-Hispanic/Pacific Islanders. Non-Hispanic African-Americans and Hispanics have the same percentage of oral contraceptive application (52.2\%) with a relatively lower figure of breast cancer incidence with $3.8 \%$ and $4.7 \%$, respectively [25]. Our study had found the percentage of oral contraceptive application with breast cancer incidence followed by a range of 3.7-13.9\%. The figure was higher in some ethnic than others as we had described, possibly due to oral contraception application percentage is known was also relatively high in the Southeast Asian region with 12.8\% [12].

Based on the risk opportunities found, it was demonstrated that there was a higher breast cancer risk in Southeast Asian regions with $\leq 5$ years' duration of oral contraceptive application was OR $=1.21(95 \% \mathrm{Cl} 0.96$ 1.52), while $>5$ years' duration of oral contraceptive use was $\mathrm{OR}=2.66$ (95\% $\mathrm{Cl} 1.79-3.94)$. Previous study also had found risk opportunities of breast cancer related to oral contraceptive included non-Hispanic Caucasians 
(HR = 1.09 (95\% Cl 1.01-1.18), non-Hispanic African Americans (HR = 0.95 (95\% Cl 0.64-1.42), and non-Hispanic Asian / Pacific Islander (HR = 0.93 (95\% Cl 0.63-1.39) [25].

Data from 39 case-control studies led from 1980 to 2006 have discovered a association of contraceptive pills with breast cancer among premenopausal [26]. Another study recommended that present utilization of contraceptive pills which substance is estrogen appears to somewhat elevate the breast cancer risk. A few factors adding to the advancement of breast disease incorporate hormones, which is estrogen itself [27-29]. The use of contraceptive pills which contains estrogen the breast tissue to be presented to large amounts of hormones for longer periods. That estrogen stimulates growth factors that exist in breast cancer cells resulting in tumor progression [30,31].

The previous research on the impact of age at beginning of utilization of the pill on the rate of breast cancer growth presumed that ladies that had begun utilizing the pill before 18 years old contracted disease 4 years sooner [32]. In a study, the researcher accepts prolonged use increases the risk. Another study found a relative risk of 2.2 with over 10 years of length of using [33]. The other study found the afinity between breast cancer and contraceptive pills use $(\mathrm{OR}=2.11)$. The investigation results show that women that utilization preventative pills have more noteworthy requirements for preventive and screening measures [34].

Based on data oral contraceptive is the most common means of contraception in the world and Southeast Asian countries, utilized by millions of women [35-37]. According to the duration of oral hormonal contraceptives use more than 5 years will increase breast cancer risk which will be higher compared to those who have never used hormonal contraception. If a person stops taking hormonal contraception for 5 years then she will have no risk of breast cancer. This result is supported by a theory found about the imbalance of the hormones estrogen and progesterone used in hormonal contraception [4,38,39]. This hormonal imbalance has resulted in a feedback mechanism that can physiologically control the number of hormones in the body when it is not functioning properly [40]. It was triggered by the estrogen receptors up regulation so that the number of hormones continues to increase. Exposure to sexual hormones over a period of more than 5 years will increase the proliferation of breast cells and increase breast cancer stem cell mitosis [41].

A meta-analysis data in this study has several limmitations. First, there were 2 potential articles should be included in this study but the full-text articles are inavailable. Second, there were 2 studies are also potentially included in data analysis yet the data presented were incomplete and different risk factors in the calculations were also performed.

Based on our analysis, as we found of the significant association of oral hormonal contraceptives use with breast cancer risk as well as increase for more than five years' duration of contraceptive pills use, we suggest people to select effective and efficient long-term contraceptive methods to prevent pregnancy, yet safe in accordance with infertility and breast cancer risk. Another suggestion is breast cancer screening programs are necessary for Southeast Asian countries.

\section{Conclusions}

This study confirms the significant correlation of more than five years' duration of oral hormonal contraceptives use and breast cancer risk in Southeast Asia. Therefore, we recommend fertile women who want to prevent 
pregnancy for a relatively long period, should use long-term contraception methods.

\section{Abbreviations}

Cls: Confidence Intervals

HR: Hazard Ratio

NOS: Newcastle-Ottawa Quality Assessment Scale

OR: Odds Ratios

POR: Pooled Odds Ratios

PRISMA: Preferred Reporting Items for Systematic Reviews and Meta-Analysis

RevMan: Review Manager

\section{Declarations}

\section{Ethics approval and consent to participate}

Not applicable.

\section{Consent for publication}

Not applicable.

\section{Availability of data and materials}

The datasets analyzed of the present study could be obtained from the corresponding author upon reasonable request.

\section{Competing interest}

The authors declared no potential conflicts of interest.

\section{Funding}

Not applicable 


\section{Authors' contributions}

RDN, TA, ID, and WAH conceived and designed the study. RDN, SLA, LL collected the data and performed analysis and interpretation. RDN wrote the first draft with critical feedback from TA, SLA, TA, WAH, and ID. All authors read, reviewed and edited the draft and approved the final version of the manuscript.

\section{Acknowledgments}

We express our gratitude to Mac Arif Hamdanas, MA for proofreading the manuscript draft.

\section{References}

1. Bray F, Ferlay J, Soerjomataram I, Siegel RL, Torre LA, Jemal A. Global cancer statistics 2018: GLOBOCAN estimates of incidence and mortality worldwide for 36 cancers in 185 countries. CA Cancer J Clin. 2018;68:394-424.

2. Collaborative Group on Hormonal Factors in Breast Cancer. Breast cancer and hormonal contraceptives: collaborative reanalysis of individual data on 53,297 women with breast cancer and 100,239 women without breast cancer from 54 epidemiological studies. 1996;347:1713-27.

3. Barnard ME, Boeke CE, Tamimi RM. Established breast cancer risk factors and risk of intrinsic tumor subtypes. Biochim Biophys Acta. 2015;1856: 73-85.

4. Haile RW, Thomas DC, McGuire V, Felberg A, John EM, Hopper JL, et al. BRCA1 and BRCA2 mutation carriers, oral contraceptive use, and breast cancer before age 50. Cancer Epidemiol Biomarkers Prev. 2006;15:1863-70.

5. Urban M, Banks E, Egger S, Canfell K, O'Connel D, Beral V, Sitas F. Injectable and Oral Contraceptive Use and Cancers of the Breast, Cervix, Ovary, and Endometrium in Black South African Women: Case-Control Study. PLoS Med. 2012; 9: e1001182.

6. Hunter DJ, Colditz GA, Hankinson SE, Malspeis S, Spiegelman D, Chen W, et al. Oral contraceptive use and breast cancer: a prospective study of young women. Cancer Epidemiol Biomarkers Prev. 2010; 19: 24962502.

7. Marchbanks PA, McDonald JA, Wilson HG, Folger SG, Mandel MG, Daling JR, et al. Oral contraceptives and the risk of breast cancer. N Engl J Med. 2002;346:2025-32.

8. Bethea TN, Rosenberg L, Hong CC, Troester MA, Lunetta KL, Bandera EV, et al. A case-control analysis of oral contraceptive use and breast cancer subtypes in the African American Breast Cancer Epidemiology and Risk Consortium. Breast Cancer Res. 2015;17:22.

9. Veisy A, Lotfinejad S, Salehi K, Zhian F. Risk of breast cancer in relation to reproductive factors in NorthWest of Iran, 2013-2014. Asian Pac J Cancer Prev. 2015;16:451-5.

10. Zare N, Haem E, Lankarani KB, Heydari ST, Barooti E. Breast cancer risk factors in a defined population: weighted logistic regression approach for rare events. J Breast Cancer. 2013;16:214-9.

11. Mansour D, Gemzell-Dannielsson K, Inki P, Jensen JT. Fertility after discontinuation of contraception: a comprehensive review of the literature. 2011;84:465-77. 
12. IARC Working Group on the Evaluation of Carcinogenic Risks to Humans. Combined Estrogen-progestogen Contraceptives and combined estrogen-progestogen menopausal therapy. IARC Monogr Eval Carcinog Risks Hum. 2007;91:1-528.

13. Nguyen J, Le QH, Duong BH, Sun P, Pham HT, Ta VT, et al. A Matched Case-Control Study of Risk Factors for Breast Cancer Risk in Vietnam. Int J Breast Cancer. 2016;2016:7164623.

14. Liberati A, Altman DG, Tetzlaff J, Mulrow C, Gotzche PC, loannidis JP, et al. The PRISMA statement for reporting systematic reviews and meta-analyses of studies that evaluate healthcare interventions: Explanation and elaboration. PloS Med. 2009;6:e1000100.

15. Wells GA, Shea B, O'Connell D, Peterson J, Welch V, Losos M, et al. The Newcastle-Ottawa Scale (NOS) for assessing the quality of non randomised studies in meta-analyses; 2009 [cited 2018 June 10]. Available from: http://www.ohri.ca/programs/clinical_epidemiology/oxford.asp.

16. Norsa'adah B, Rusli BN, Imran AK, Naing I, Winn T. Risk factors of breast cancer in women in Kelantan, Malaysia. Singapore Med J. 2005;46:698-705.

17. Gibson LJ, Héry C, Mitton N, Gines-Bautista A, Parkin DM, Ngelangel C, Pisani P. Risk factors for breast cancer among Filipino women in Manila. Int J Cancer. 2010;126:515-21.

18. Matalqah L, Radaideh K, Yusoff ZM, Awaisu A. Predictors of breast cancer among women in a northern state of Malaysia: a matched case-control study. Asian Pac J Cancer Prev. 2011;12:1549-53.

19. Poosari A, Promthet S, Kamsa-ard S, Suwanrungruang K, Longkul J, Wiangnon S. Hormonal contraceptive use and breast cancer in Thai women. J Epidemiol. 2014;24:216-20

20. Lee CP, Irwanto A, Salim A, Yuan JM, Liu J, Koh WP, Hartman M. Breast cancer risk assessment using genetic variants and risk factors in a Singapore Chinese population. Breast Cancer Res. 2014;16(3): R64.

21. Trieu PDY, Mello-Thoms C, Peat JK, Do TD, Brennan PC. Risk Factors of Female Breast Cancer in Vietnam: A Case-Control Study. Cancer Res Treat. 2017;49(4):990-1000.

22. Chaveepojnkamjorn W, Pichainarong N, Thotong R, Sativipawee P, Pitikultang S. Relationship between Breast Cancer and Oral Contraceptive Use among Thai Premenopausal Women: a Case-Control Study. Asian Pac J Cancer Prev. 2017;18(5):1429-1433.

23. Tan MM, Ho WK, Yoon SY, Mariapun S, Hasan SN, Lee DS, et al. A case-control study of breast cancer risk factors in 7,663 women in Malaysia. PLoS One. 2018;13(9):e0203469.

24. Wahidin M, Djuwita R, Adisasmita A. Oral Contraceptive and Breast Cancer Risks: a Case-Control Study in Six Referral Hospitals in Indonesia. Asian Pac J Cancer Prev. 2018;19(8):2199-2203.

25. Xie C, Shao N, He L, Li X, Li C, Li J, Su D. Exploration of Racial Differences in Reproductive Factors for Breast Cancer among Women aged 55-74. J Cancer. 2018; 9: 469-478.

26. Kahlenborn C, Modugno F, Potter DM, Severs WB. Oral contraceptive use as a risk factor for premenopausal breast cancer: a meta-analysis. Mayo Clin Proc. 2006;81(10):1290-302.

27. Beaber EF, Malone KE, Tang MT, Barlow WE, Porter PL, Daling JR, Li Cl. Oral contraceptives and breast cancer risk overall and by molecular subtype among young women. Cancer Epidemiol Biomarkers Prev. 2014;23(5):755-64.

28. Hall KS, Trussell J, Schwarz EB. Progestin-only contraceptive pill use among women in the United States. Contraception. 2012;86:653-8. 
29. Benagiano G, Primiero FM, Farris M. Clinical profile of contraceptive progestins. Eur J Contracept Reprod Health Care. 2004;9:182-93.

30. Kumle M, Weiderpass E, Braaten T, Persson I, Adami HO, Lund E. Use of oral contraceptives and breast cancer risk: The Norwegian-Swedish Women's Lifestyle and Health Cohort Study. Cancer Epidemiol Biomarkers Prev. 2002;11:1375-81.

31. Marchbanks PA, Curtis KM, Mandel MG, Wilson HG, Jeng G, Folger SG, et al. Oral contraceptive formulation and risk of breast cancer. Contraception. 2012;85:342-50.

32. Brinton LA, Hoover R, Szklo M, Fraumeni JF Jr. Oral contraceptives and breast cancer. Int J Epidemiol. 1982;11:316-32.

33. Imkampe AK, Bates T. Correlation of age at oral contraceptive pill starts with age at breast cancer diagnosis. Breast J. 2012; 18(1):35-40.

34. Veisy A, Viga M. The role of oral contraceptive pills on increased risk of breast cancer in North West of Iran. Clin Sci Rep. 2018; 1(2): 2-4.

35. Najafi-Sharjabad F, Zainiyah Syed Yahya S, Abdul Rahman H, Hanafiah Juni M, Abdul Manaf R. Barriers of modern contraceptive practices among Asian women: a mini literature ireview. Glob J Health Sci. 2013;5(5):181-92.

36. Ahmed S, Li Q, Liu L, Tsui AO. Maternal deaths averted by contraceptive use: an analysis of 172 countries. Lancet. 2012;380:111-125.

37. Mir AS, Malik R. Emergency contraceptive pills: Exploring the knowledge and attitudes of community health workers in a developing Muslim country. N Am J Med Sci. 2010;2(8):359-364.

38. Jarosz AC, Jamnik J, El-Sohemy A. Hormonal contraceptive use and prevalence of premenstrual symptoms in a multiethnic Canadian population. BMC Women Health. 2017;17(1):87.

39. Dall GV, Britt KL. Estrogen Effects on the Mammary Gland in Early and Late Life and Breast Cancer Risk. Front Oncol. 2017;7:110.

40. Colditz GA, Bohlke K, Berkey CS. Breast cancer risk accumulation starts early: prevention must also. Breast Cancer Res Treat. 2014;145(3):567-79.

41. Nindrea RD, Aryandono T, Lazuardi L. Breast Cancer Risk From Modifiable and Non-Modifiable Risk Factors among Women in Southeast Asia: A Meta-Analysis. Asian Pac J Cancer Prev. 2017;18(12):3201-3206.

\section{Tables}

Table 1. Systematic review of duration of oral contraceptive use with breast cancer risk in Southeast Asian women 


\begin{tabular}{|c|c|c|c|c|c|c|c|c|c|}
\hline \multirow[t]{3}{*}{ First Author } & \multirow[t]{3}{*}{ Region } & \multirow{3}{*}{$\begin{array}{l}\text { Study } \\
\text { Type }\end{array}$} & \multirow{3}{*}{$\begin{array}{c}\text { Patients } \\
\text { Characteristic }\end{array}$} & \multirow{3}{*}{$\begin{array}{l}\text { Duration } \\
\text { (years) }\end{array}$} & \multicolumn{4}{|c|}{ Number of Sample } & \multirow[t]{3}{*}{ NOS } \\
\hline & & & & & \multicolumn{2}{|c|}{ Cases } & \multicolumn{2}{|c|}{ Control } & \\
\hline & & & & & Total & Exposure & Total & Exposure & \\
\hline $\begin{array}{l}\text { Norsaadah et al } \\
\text { [16] }\end{array}$ & Malaysia & $\begin{array}{l}\text { Case } \\
\text { control }\end{array}$ & $\begin{array}{l}\text { Aged 26-70 } \\
\text { years }\end{array}$ & $\leq 5$ & 147 & 53 & 147 & 36 & 6 \\
\hline Gibson et al [17] & Philippines & $\begin{array}{l}\text { Case } \\
\text { control }\end{array}$ & $\begin{array}{l}\text { Aged 35-64 } \\
\text { years }\end{array}$ & $\leq 5$ & 123 & 16 & 978 & 125 & 6 \\
\hline $\begin{array}{l}\text { Matalqah et al (a) } \\
\text { [18] }\end{array}$ & Malaysia & $\begin{array}{l}\text { Case } \\
\text { control }\end{array}$ & $\begin{array}{l}\text { Aged 23-83 } \\
\text { years, three } \\
\text { ethnic groups } \\
\text { (Malay, } \\
\text { Chinese and } \\
\text { Indian) }\end{array}$ & $\leq 5$ & 150 & 27 & 150 & 21 & 7 \\
\hline $\begin{array}{l}\text { Matalqah et al (b) } \\
\text { [18] }\end{array}$ & Malaysia & $\begin{array}{l}\text { Case } \\
\text { control }\end{array}$ & $\begin{array}{l}\text { Aged 23-83 } \\
\text { years, three } \\
\text { ethnic groups } \\
\text { (Malay, } \\
\text { Chinese and } \\
\text { Indian) }\end{array}$ & $>5$ & 150 & 13 & 150 & 6 & 7 \\
\hline $\begin{array}{l}\text { Poosari et al (a) } \\
\text { [19] }\end{array}$ & Thailand & Cohort & $\begin{array}{l}\text { Aged 30-69 } \\
\text { years }\end{array}$ & $\leq 5$ & 3,664 & 14 & 2,153 & 11 & 8 \\
\hline $\begin{array}{l}\text { Poosari et al (b) } \\
\text { [19] }\end{array}$ & Thailand & Cohort & $\begin{array}{l}\text { Aged 30-69 } \\
\text { years }\end{array}$ & $>5$ & 5,597 & 45 & 2,153 & 11 & 8 \\
\hline Lee et al [20] & Singapore & Cohort & $\begin{array}{l}\text { Aged } 45-74 \\
\text { years, } \\
\text { Chinese } \\
\text { population }\end{array}$ & $\leq 5$ & 411 & 39 & 1,212 & 81 & 7 \\
\hline Nguyen et al [13] & Vietnam & $\begin{array}{l}\text { Case } \\
\text { control }\end{array}$ & $\begin{array}{l}\text { Aged } 25-75 \\
\text { years }\end{array}$ & $\leq 5$ & 294 & 25 & 294 & 13 & 7 \\
\hline Trieu et al [21] & Vietnam & $\begin{array}{l}\text { Case } \\
\text { control }\end{array}$ & $\begin{array}{l}\text { Aged } 27-74 \\
\text { years }\end{array}$ & $\leq 5$ & 269 & 79 & 519 & 134 & 7 \\
\hline $\begin{array}{l}\text { Chaveepojnkomjorn } \\
\text { et al (a) [22] }\end{array}$ & Thailand & $\begin{array}{l}\text { Case } \\
\text { control }\end{array}$ & $\begin{array}{l}\text { Aged }<45 \\
\text { years }\end{array}$ & $\leq 5$ & 257 & 42 & 257 & 44 & 7 \\
\hline $\begin{array}{l}\text { Chaveepojnkomjorn } \\
\text { et al (b) [22] }\end{array}$ & Thailand & $\begin{array}{l}\text { Case } \\
\text { control }\end{array}$ & $\begin{array}{l}\text { Aged }<45 \\
\text { years }\end{array}$ & $>i 5$ & 257 & 125 & 257 & 51 & 7 \\
\hline Tan et al [23] & Malaysia & $\begin{array}{l}\text { Case } \\
\text { control }\end{array}$ & $\begin{array}{l}\text { Aged 40-74 } \\
\text { years, three } \\
\text { ethnic groups } \\
\text { (Malay, } \\
\text { Chinese and } \\
\text { Indian) }\end{array}$ & $\leq 5$ & 3,683 & 935 & 3,980 & 1,145 & 8 \\
\hline $\begin{array}{l}\text { Wahidi et al (a) } \\
\text { [24] }\end{array}$ & Indonesia & $\begin{array}{l}\text { Case } \\
\text { control }\end{array}$ & $\begin{array}{l}\text { Aged } 40-49 \\
\text { years }\end{array}$ & $\leq 5$ & 381 & 77 & 381 & 53 & 7 \\
\hline $\begin{array}{l}\text { Wahidi et al (b) } \\
\text { [24] }\end{array}$ & Indonesia & $\begin{array}{l}\text { Case } \\
\text { control }\end{array}$ & $\begin{array}{l}\text { Aged } 40-49 \\
\text { years }\end{array}$ & $>5$ & 381 & 58 & 381 & 24 & 7 \\
\hline \multicolumn{5}{|c|}{ Total } & 15,764 & 1,548 & 13,012 & 1,755 & \\
\hline
\end{tabular}

Abbreviation: NOS, Newcastle-Ottawa Quality Assessment Scale

Table 2. Subgroup analysis for oral contraceptive use and breast cancer risk in Southeast Asia 


\begin{tabular}{lcccc}
\hline \multicolumn{1}{c}{ Subgroups } & Number of studies & Pooled OR & \multicolumn{2}{c}{ Heterogeneity } \\
\cline { 4 - 6 } & & $(95 \% \mathrm{CI})$ & $\mathrm{I}^{2}(\%)$ & $\mathrm{p}$ \\
\hline Study design & 3 & $1.34(0.98-1.84)$ & 21 & 0.28 \\
Cohort & 7 & $1.52(1.06-2.18)$ & 90 & $<0.001$ \\
Case control & & & & \\
Study quality & & $1.51(1.09-2.10)$ & 88 & $<0.001$ \\
High (NOS scores $\geq 7)$ & 2 & $1.35(0.80-2.27)$ & 48 & 0.17 \\
Low (NOS scores $<7)$ & & &
\end{tabular}

Abbreviation: CI, confidence interval; OR, odds ratio; $\mathrm{p}<0.05$ considered statistically significant; significant heterogenity $>50 \%$

Table 3. The Duration of oral contraceptive use and breast cancer risk in Southeast Asian countries

\begin{tabular}{lcccc}
\hline \multicolumn{1}{c}{ Countries } & Number of studies & Pooled OR & \multicolumn{2}{c}{ Heterogeneity } \\
\cline { 4 - 6 } & & $(95 \% \mathrm{CI})$ & $\mathrm{I}^{2}(\%)$ & $\mathrm{p}$ \\
\hline Oral contraceptive for $\mathbf{5}$ 5 years & 1 & $1.57(1.07-2.30)$ & $\mathrm{n} / \mathrm{a}$ & $\mathrm{n} / \mathrm{a}$ \\
Indonesia & 3 & $1.19(0.71-1.99)$ & 79 & 0.009 \\
Malaysia & 1 & $1.02(0.58-1.78)$ & $\mathrm{n} / \mathrm{a}$ & $\mathrm{n} / \mathrm{a}$ \\
Philippines & 2 & $0.89(0.60-1.33)$ & 0 & 0.61 \\
Thailand & 1 & $1.46(0.98-2.18)$ & $\mathrm{n} / \mathrm{a}$ & $\mathrm{n} / \mathrm{a}$ \\
Singapore & 2 & $1.41(0.88-2.27)$ & 44 & 0.18 \\
Vietnam & & & & \\
Oral contraceptive for $>5$ years & 1 & $2.67(1.62-4.40)$ & $\mathrm{n} / \mathrm{a}$ & $\mathrm{n} / \mathrm{a}$ \\
Indonesia & 1 & $2.28(0.84-6.16)$ & $\mathrm{n} / \mathrm{a}$ & $\mathrm{n} / \mathrm{a}$ \\
Malaysia & 2 & $2.56(1.08-6.08)$ & 80 & 0.02 \\
Thailand & & & &
\end{tabular}

Abbreviation: CI, confidence interval; $\mathrm{n} / \mathrm{a}$, not available; OR, odds ratio; $\mathrm{p}<0.05$ considered statistically significant; significant heterogenity $>50 \%$

\section{Figures}




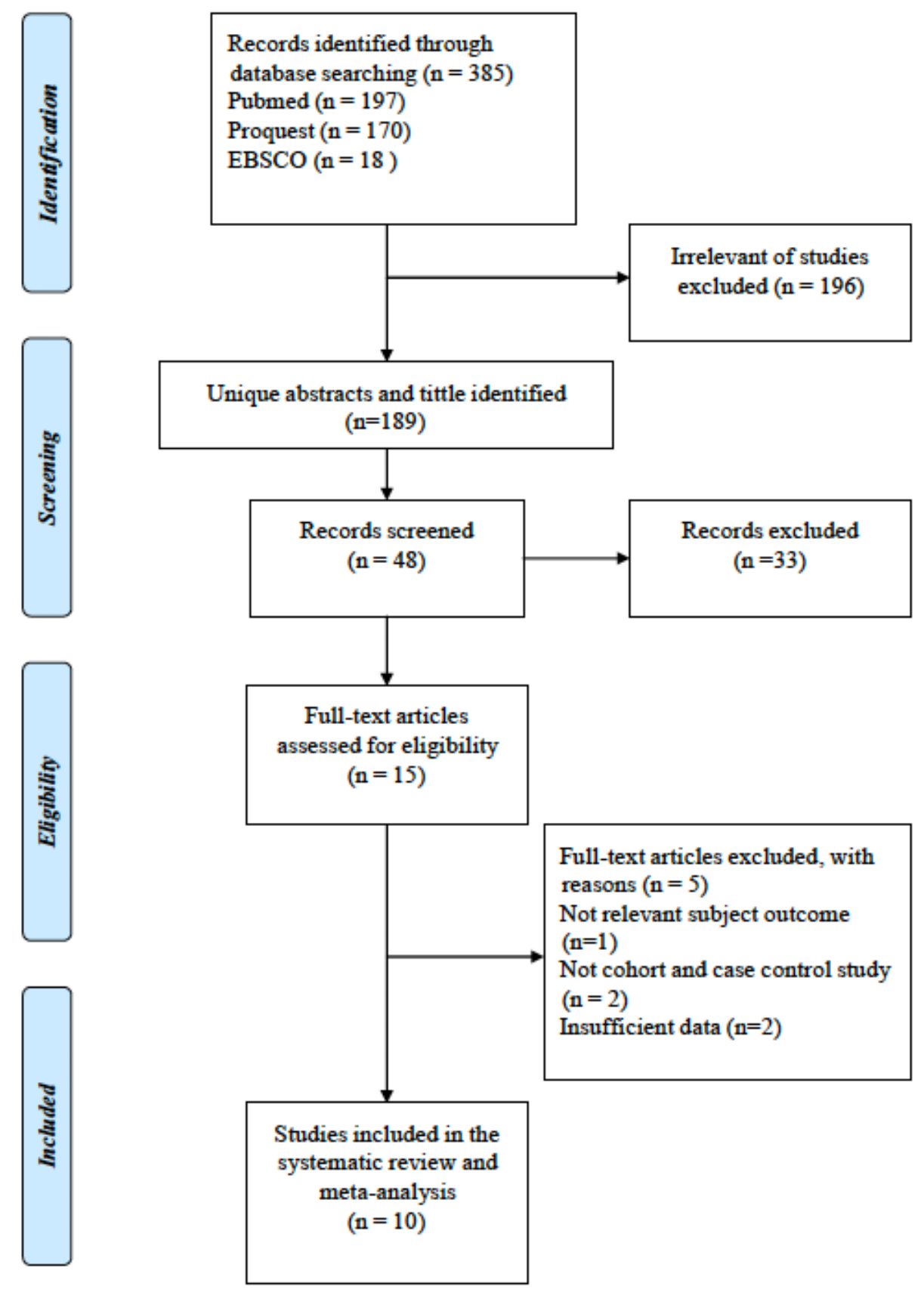

Figure 1 
Cases Control Odds Ratio

Study or Subgroup

Total Weight M-H, Random, $95 \% \mathrm{Cl}$ Year

1.1.1 Oral contraceptive for $<=5$ years

Norsa'adah et al 2005

Gibson et al 2010

Matalqah et al 2011 (a)

Lee et al 2014

Poosari et al 2014 (a)

Nguyen et al 2016

Chaveepojnkamjorn et al 2017 (a)

Trieu et al 2017

Wahidi et al 2018 (a)

Tan et al 2018

Subtotal $(95 \% \mathrm{Cl})$

Total events

$\begin{array}{lllll}53 & 147 & 36 & 147 & 9.4 \%\end{array}$

$\begin{array}{lllll}16 & 123 & 125 & 978 & 8.5 \%\end{array}$

$\begin{array}{lllll}27 & 150 & 21 & 150 & 7.6 \%\end{array}$

$\begin{array}{lllll}39 & 411 & 81 & 1212 & 11.3 \%\end{array}$

$\begin{array}{lllll}14 & 3664 & 11 & 2153 & 5.7 \%\end{array}$

$\begin{array}{lllll}25 & 294 & 13 & 294 & 6.7 \%\end{array}$

$\begin{array}{lllll}42 & 257 & 44 & 257 & 10.1 \%\end{array}$

$\begin{array}{lllll}79 & 269 & 134 & 519 & 12.7 \%\end{array}$

$\begin{array}{lllll}77 & 381 & 53 & 381 & 11.6 \%\end{array}$

$\begin{array}{lllll}935 & 3683 & 1145 \quad 3980 & 16.5 \%\end{array}$

$9379 \quad 10071 \quad 100.0 \%$

$1307 \quad 1663$

Heterogeneity: Tau $^{2}=0.08 ; \mathrm{Chi}^{2}=29.99, \mathrm{df}=9(\mathrm{P}=0.0004) ; \mathrm{I}^{2}=70 \%$

Test for overall effect: $Z=1.62(P=0.11)$

1.1.2 Oral contraceptive for $>5$ years

\begin{tabular}{|c|c|c|c|c|c|c|c|}
\hline Matalqah et al $2011(b)$ & 13 & 150 & 6 & 150 & $12.3 \%$ & $2.28[0.84,6.16]$ & 2011 \\
\hline Poosari et al $2014(b)$ & 45 & 5597 & 11 & 2153 & $21.8 \%$ & $1.58[0.81,3.06]$ & 201 \\
\hline Chaveepojnkamjorn et al 2017 (b) & 125 & 257 & 51 & 257 & $36.3 \%$ & $3.83[2.58,5.66]$ & 2 \\
\hline Wahidi et al 2018 (b) & 58 & 381 & 24 & 381 & $29.7 \%$ & $2.67[1.62,4.40]$ & \\
\hline Subtotal $(95 \% \mathrm{CI})$ & & 6385 & & 2941 & $100.0 \%$ & $2.66[1.79,3.94]$ & \\
\hline events & 4 & & 92 & & & & \\
\hline
\end{tabular}

Heterogeneity: $\operatorname{Tau}^{2}=0.07 ; \mathrm{Chi}^{2}=5.50, \mathrm{df}=3(\mathrm{P}=0.14) ; \mathrm{I}^{2}=45 \%$

Test for overall effect: $Z=4.87$ ( $P=0.00001$ )
$1.74[1.05,2.88] 2005$

$1.02[0.58,1.78] 2010$

$1.35[0.72,2.51] 2011$

$1.46[0.98,2.18] 2014$

$0.75[0.34,1.65] 2014$

$2.01[1.01,4.01] 2016$

$0.95[0.60,1.50] 2017$

$1.19[0.86,1.66] 2017$

$1.57[1.07,2.30] 2018$

$0.84[0.76,0.93] 2018$

$1.21[0.96,1.52]$
Odds Ratio

M-H, Random, $95 \% \mathrm{Cl}$

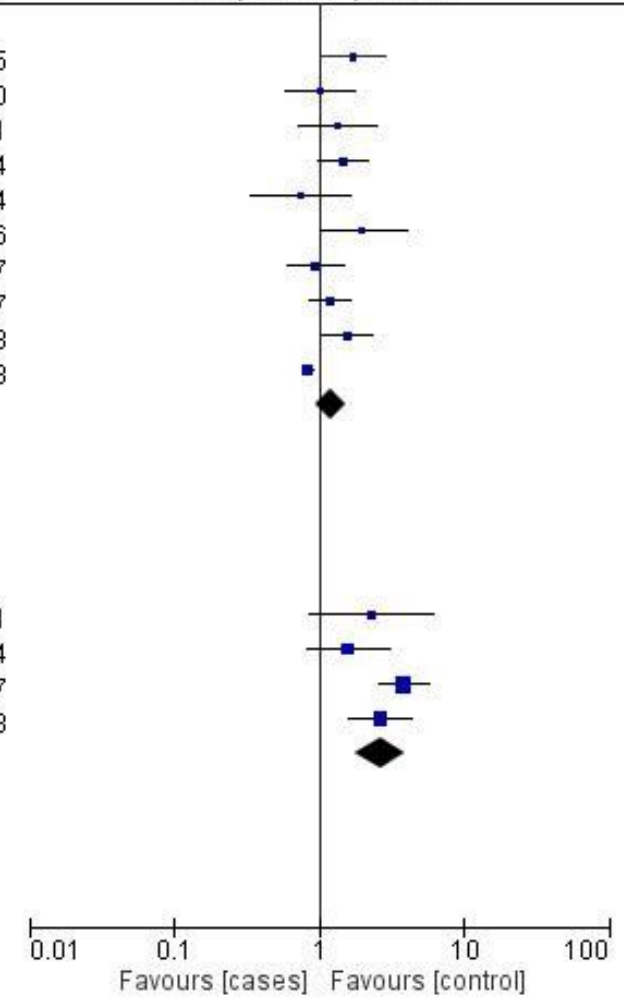

\section{Figure 2}


Funnel plot with pseudo $95 \%$ confidence limits

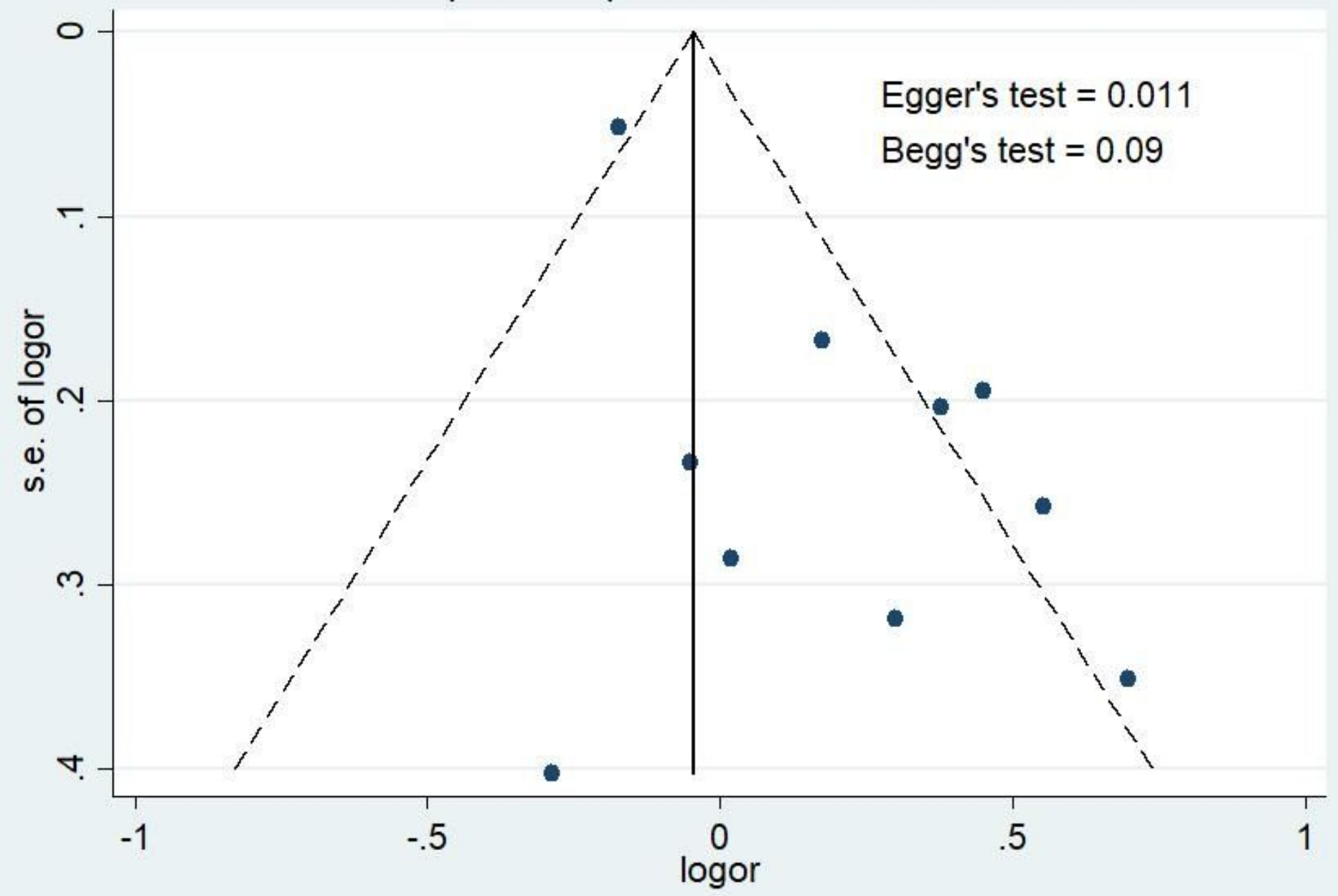

Figure 3 
Funnel plot with pseudo $95 \%$ confidence limits

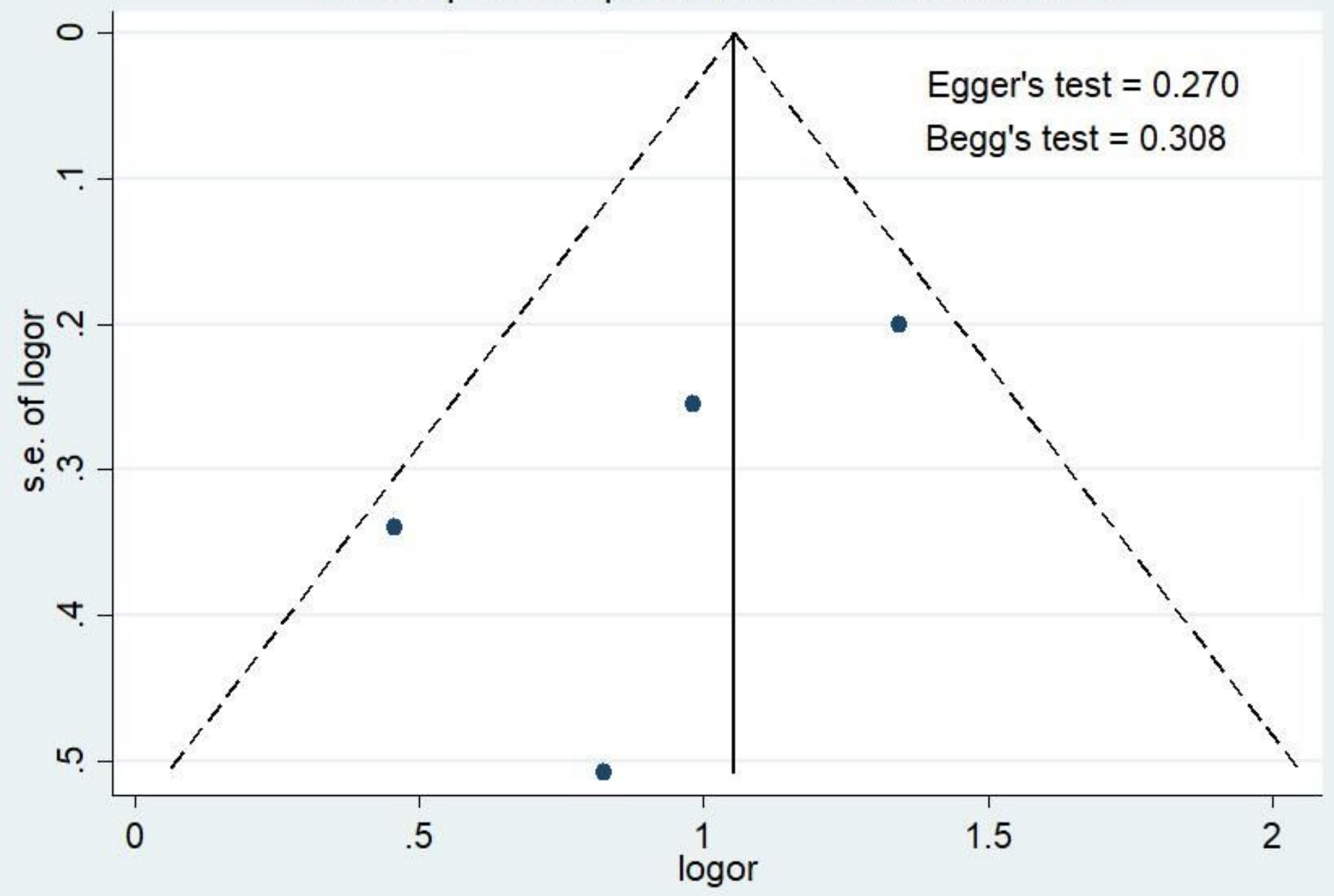

Figure 4

\section{Supplementary Files}

This is a list of supplementary files associated with this preprint. Click to download.

- PRISMAchecklistBCAND1902794.doc 